\title{
Influences of Power Distance and Uncertainty Avoidance on Innovative Work Behavior: Mediation effects of Self-Leadership ${ }^{*}$
}

Jungsik Kim $^{* *}$

Kwangwoon University

\author{
Fan Zhou ${ }^{* * *}$
}

\begin{abstract}
This study examines the relationships between employees' cultural value orientations and their innovative work behaviors and the mediation effects of self-leadership in the relationships. Four hundred and eighty two employees working at various firms in Korea and China responded to a questionnaire consisting of measures designed to assess uncertainty avoidance, power distance, and innovative work behavior. Analyses of the data revealed that power distance was negatively related to innovative work behavior for both respondents while uncertainty avoidance was positively related to innovative work behavior. The mediation effects of self-leadership were also found. This study contributes to current research literature by providing empirical evidence for the role of self-leadership in the mechanism linking individuals' cultural value orientations and innovative work behavior. The study also discusses similarities and differences in the patterns of power distance, uncertainty avoidance, innovative work behavior, and self-leadership across Korean and Chinese respondents and their implications in changing business environment.
\end{abstract}

Key words : power distance, uncertainty avoidance, self-leadership, innovative work behavior

\footnotetext{
* The work reported in this paper was conducted during the sabbatical year of Kwangwoon University in 2015.

** Jungsik Kim, $1^{\text {st }}$ author \& corresponding author, Professor of Management at Kwangwoon University

*** Fan Zhou received master's degree from Kwangwoon University.
} 
Although innovation is a prerequisite for success to most organizations(Chakraborti, 2003), it can be also stressful to individual employees because they need to cope with many types of changes that include work procedure, work role and responsibility, and task of learning new knowledge, etc.(Staw \& Boettger, 1990).

As the future success of adopted innovation is uncertain, individuals often experience anxiety and worries on whether innovation will be beneficial or harmful to themselves(Teece \& Leih, 2016). Thus, individuals, although being the critical key players for innovation, can be either more initiative or be more reluctant to participate in the innovation process depending on their acceptance of uncertainty. Another significant barrier of innovation is the perceived power and hierarchy existing within the organization and inside individuals' minds. Innovation requires collaborative efforts among many individuals in the organization. Even if an individual has an excellent innovative idea and feels highly confident of its success in future, innovation cannot be possible unless one successfully works with others in the organization to endorse the idea, obtain resource supply, support, and agreement for decision making for the promotion, execution, and implementation of the innovative ideas(Scott \& Bruce, 1994). Then, if a highly hierarchical power based culture exists within the organization, individuals may feel it difficult to strongly proceed with the innovative ideas because they expect their ideas and efforts will be hardly accepted by others (Klein \& Knight, 2005).

These two issues are closely related with the cultural value orientations, uncertainty avoidance and power distance which Hofestde(1980, 2001) theorized. Yet, only a limited number of studies discussed the culture-innovation relationship in general(McLean, 2005; Oldham \& Cummings, 1996) and, if any, those studies are currently restricted to show only the existence of bivariate relationships between cultural dimensions and innovation or to provide post-hoc explanation for the relationships found(Gelfand, Eerez, \& Aycan, 2007). As a result, the efforts to find the mechanism linking cultural value orientations with innovation at individual level are still absent in current literature.

One possible way is by looking at the role of self-leadership. Innovation expects that individuals are not just passive agents but rather they must be guiding themselves. Because innovation is a risky idea and does not often come with immediate rewards, individuals need to control oneself with self-reward and self-feedback that their efforts for innovation will have positive outcomes. These are the several characteristics that the concept of self-leadership emphasizes on (Anderson \& Manz, 1998). Self-leadership drives people from internal motivation to act on and produce concrete outcomes at work with minimum external managerial guidance, particularly in high uncertainty situation(Pearce \& Manz, 2005). Yet, there is currently no 
empirical evidence linking power distance and uncertainty avoidance with innovation through self-leadership although power distance and uncertainty avoidance have been studied in numerous studies(see Daniels \& Gerguras, 2014 for review).

Therefore, this study aims to investigate the relationship by focusing on the innovative work behavior, which corresponds to the innovation at an individual level. We pursue this goals by analyzing a cross-national sample consisting of Korean and Chinese respondents. Analyses of a cross-national sample can give us a more reliable conclusion through extended scope of samples with different cultural backgrounds. It also can provide practical knowledge and insights to the human resources management experts in multi-cultural or multi-national organization which is increasing in numbers recently.

\section{Innovative Work Behavior}

Innovative work behavior is defined as "the intentional creation, introduction and application of new ideas within a work role, group or organization for benefit of role performance, the group, or the organization"(Janssen, 2000). Although innovation, creativity, and innovative work behavior are often interchangeably used in research(Scott \& Bruce, 1994), innovative work behavior is a concept that links between creativity and innovation. Creativity refers to a generation of novel and useful ideas, whereas innovation refers to outcomes achieved eventually after successful promotion and implementation of creative ideas(Amabile et al., 1996; Woodman et al., 1993). Also, while creativity is quite a general and an abstractive concept that includes cognitive ability, response, and behavioral patterns(Amabile et al., 1996), innovative work behavior is a more concrete observable behavior. A person's creative ideas cannot be recognized unless it is expressed and accepted at a behavioral level in organizations: A creative employee should show innovative work behavior to move on innovation. Innovation takes three steps. First, individuals come up with new solutions and ideas. Second, new solutions and ideas are promoted to build legitimate support from the organization. Finally, the new ideas or solutions need to be developed into a prototype or model of the innovation that can be applied within a work group in the organization (Janssen, 2004; Kanter, 1988). Therefore, innovative work behavior is a concrete behavior playing an important role of linking the generation of creative ideas and their evolution to innovation.

\section{Cultural Value Orientation and innovative work behavior}

Of many antecedents of innovative work behavior(Janssen, 2004; Yuan \& Woodman, 2010; Zhou \& Woodman, 2003), we focus on individuals' cultural value orientation as an 
important antecedent of innovative work behavior in this study.

Innovation is a work in which individuals need to constantly work with others to share creative ideas, promote the ideas and solutions, legitimate them by getting support from others inside, and finally apply a model of the innovation within the organization(Kanter, 1988). Similarly, culture is a set of values and beliefs that members in a society collectively share (Schwartz, 1999). Individual's cultural values are often an indirect indicators of the cultural values that prevail in the organization(Schwartz, 1999). Thus, the more individuals share cultural values with others, the more they are likely to share common ideas regarding innovation, too. Especially, organizational culture is reflected in individuals' cultural orientations at the organizational level. Thus, the understanding of organizational culture can help us to understand the process of innovation. For example, Hogan and Coote(2013), using Schein's organizational culture model demonstrated the positive effects of values that support innovation on measures of firm performance.

In this study, we investigate the relationship between individuals' cultural value orientation and innovative work behavior by focusing on power distance and uncertainty avoidance that Hofstede(1980) identified. The relevance of power distance and uncertainty avoidance to innovative work behavior are as follows.

\section{Power Distance and innovative work behavior}

Power distance refers to the degree to which individuals, accept inequalities in power, status, wealth as unavoidable, legitimate, or sometimes functional(Hofstede, 1980). In organizational context, the meaning of power distance often corresponds to the extent to which individuals believe that supervisors should have more power and authority to influence employees' actions and behaviors(Dorfman \& Howell, 1988).

According to literature, power distance in organizations influences innovative work behavior through interpersonal interactions including communication(Alves et al., 2006). In high power distance culture organization, individuals are often a passive receiver and the communication for direction and decision making occurs in top-down manner(House et al., 2004; Javidan \& House, 2001). Although sharing information is a crucial factor in the innovation process(Goldsmith \& Witt, 2005; Lyons \& Hendersen, 2005), the level and quantity of information exchanged among the employees is limited in high power distance environment (Bialas, 2009). Innovation process that occurs in three steps, generation of creative ideas and promotion and implementation of the ideas (Scott \& Bruce, 1994). Whereas idea generation involves mostly individual activities, the promotion and realization of innovative ideas require substantial social communication. Thus, if high power distance organizational culture limits 
active social interactions, it can prevent the creative ideas from developing into concrete forms of innovation outcomes. Empirical evidence supports this rationale. It is known that bureaucracy with high hierarchy reduces creativity(Herbig \& Dunphy, 1998). Also, negative correlation between patented invention and power distance(Shane, 1992), negative effect by power distance on trade-marks per capita (Shane, 1993) and on economic creativity in a country(Williams \& McQuire, 2005) are reported. Thus, we believe that power distance will be negatively related to innovative work behavior.

H1: Power distance is negatively related to innovative work behavior.

Uncertainty Avoidance and innovative work behavior

Uncertainty is a state closely related the innovation. People often experience a high sense of uncertainty when their organization seeks for the innovation process because it typically applies new ideas, solutions, and work procedures different from previous procedures and routines that they have been familiar with(Kotter \& Schlesinger, 1979). Thus, individuals in an organization may resist to innovation because uncertainty is a stressful state. In general, uncertainty avoidance refers to the degree to which individuals avoid anxieties associated with an unpredictable future(Hofstede, 2001). From individuals' perspective, uncertainty avoidance also means the level of stress that individuals experience when facing the unknown(Gupta, 2011; Hofstede, 2001; Venkataraman et al, 1993).

A number of studies suggest a negative relationship between uncertainty avoidance and innovative work behavior. Individuals try to avoid uncertainty by conforming to reliable control such as social norms, rituals, and conventional practices(House et al., 2002; Schneider, 1989). However, if people passively stick with rules and controls, they are less likely able to produce new create ideas and new products(Neubert \& Wu, 2006; Yan \& Hunt, 2005). Miron, Erez, and Naveh(2004) reported that the conformity culture in $\mathrm{R} \& \mathrm{D}$ teams was negatively related to innovation. Similarly, Jansen, Van Den Bosch, and Volberda(2006) also reported a study that European financial service firms with centrality and controlling culture encouraged exploration and novel ideas. Thus, Neck \& Houghton(2006) rationalizes that high uncertainty avoidance culture tend to be more controlling and less delegating, which in turn produces less creativity and innovation. In comparison, people with low uncertainty avoidance can be more tolerant with ambiguity. They are less rule-oriented, taking more risks, and more likely to accept change while exploring more novel ideas, which is the foundation of innovation(Erez \& Nouri, 2010). The same phenomenon is observed at a macro level: uncertainty avoidance had a negative effect 
on the number of trademarks per capita(Shane, 1993) and economic creativity of a country (Williams \& McQuire, 2005). Therefore, we propose that a negative relationship exists between uncertainty avoidance and innovative work behavior.

H2: Uncertainty avoidance is negatively related to innovative work behavior.

Self-Leadership and Innovative Work Behavior

As innovation is a complex process(Scott and Bruce, 1994), there exist many obstacles and psychological frustration to organizational members on the route to innovation. Thus, Howell(2005) claims that the success of innovation requires individuals who have confidence, persistence, enthusiasm, and willingness to risk their privilege in current status, and psychological stability to resist the stress from the insecurity and uncertainty occurring during the innovation process. In other words, individuals need to own a strong internal force that pushes them to proceed when facing the obstacles in innovation(Shalley \& Gilson, 2004).

We propose that key personal elements for such activities are well reflected in the concept of self-leadership. Self-leadership is a process through which individuals regulate and mange themselves to attain desired goals by using three primary strategies(Houghton \& Yaho, 2005;
Prussia, Anderson \& Manz, 1998). Behaviorfocused strategy is to manage behaviors to successful outcomes though self-goal setting, self-reward, self-punishment, self-observation, and self-cue. Natural reward strategy is to seek for pleasant and enjoyable work activities by modifying perceptions associated with task performance to increase self-competence and self-control. Constructive thought strategy refers to managing desirable thought patterns to replace dysfunctional beliefs, assumptions, and mental imagery with positive ones(Manz \& Neck, 1999).

People with good self-leadership skills can produce innovative behaviors more effectively through self-leadership strategies(Houghton et al., 2003; Manz \& Neck, 1999). For instance, constructive thought strategy becomes essential during the first stage of the innovation process recognizing a problem and generating new ideas and solutions(Manz \& Neck, 1999). When generating new ideas, individuals may be afraid of criticism and vulnerable to dysfunctional thinking due to lack of confidence. As a result, individuals with good self-leadership are able to suggest solutions with a more safety through constructive thought.

Supporting this rationale, Carmeli, Meitar, and Weisberg(2006), found a positive relationship between self-leadership and innovative behaviors rated by self and supervisor. Also, Phelan and Young(2003) found a significant relationship between self-leadership and creativity. Neubert 
and Wu(2006) also reported a positive association between self-leadership with creativity and in-role performance among Chinese. A similar result is reported in Korea(Yang, Cheong, \& Park, 2013). Along with empirical evidence, many plausible links between self-leadership, creativity, and innovation are discussed in comprehensive review by Diliello and Houghton's (2006). Therefore, it is expected that the individuals with good self-leadership will produce more innovative work behaviors.

\section{Mediation Effects of Self-Leadership}

We propose the mediation effects of self-leadership between cultural value orientations and innovative work behavior. Researchers hint that culture make differences in prevalence of self-leadership. Alves et al.(2006) used Hofstede's (2001) culture framework to develop a number of propositions regarding how self- leadership differs across cultures. When Hofstede (1980) defined culture as "collective programming of shared values," he claims that culture exists at group and societal levels and it also operates at lower individual level since culture and individuals mutually shaped over time. This view was later supported by Markus and Kitayama(1991) in their concept of self-construal through which culture operating at group or societal levels is internalized at individual level and eventually guides individuals' cognition, motivation, and emotion. More recently, Hong and Mallorie(2004) in their Constructivist Culture Model proposes that people are not a passive reflector of culture but an active agent who makes judgments depending on interpreting situational cultural cues provided in a given situation. Therefore, we view that self-leadership plays a similar role as self-construals and the cultural value orientations such as power distance and uncertainty avoidance are likely to affect innovative work behavior through self-leadership.

Existing literature supports that both power distance and uncertainty avoidance are related with self-leadership. Starting with power distance, it is observed in three types of decision making: styles of decision making, types of decision making, and fear to disagree with superiors(Alves et al., 2006). In other words, power distance is concerned with who decides what in organizations and how that decision process is made. Self-leadership assumes that individuals have some autonomy and decision-making capacity to set and perform towards their own goals(Alves et al., 2006). Thus, it can be said that power distance can create the environment to encourage or discourage self-leadership.

In low power distance culture, followers in an organization tend to have more opportunities to share important information and participate in decision-making. For example, the US, low power distance society, tends to give individuals more freedom to practice self-leadership(Alves et al., 2006). In contrast, in high power distance culture paternalistic rule is favored over 
participatory democracy and decision-making is centralized(Hannay, 1991). As a result, leadership tends to be directive in nature in high power distance culture, whereas it is more participative in low power distance culture(Disckson et al., 2003).

If we take a specific example focusing on self-leadership strategy, constructive thought pattern can be essential during the first stage of the innovation process-recognizing a problem and generating new ideas and solutions. Because new ideas are different from what they usually perform within organization's established work system and thus, they create a sense of anxiety and uncertainty among workers. Individuals who effectively use constructive thought strategy can focus on potentially available opportunities in times of difficulties, rather than thinking about the difficulties as obstacles(Manz, 1992; Neck \& Manz, 1992). Self-reward strategy can be favorable to innovative work behavior by providing positive self-corrective feedback(Manz \& Neck, 1999). With innovative behaviors often different from routine work behaviors, individuals may feel it hard to imagine link between innovative behavior and successful outcome until it is fully established. Thus, it is hard to receive immediate positive feedback from others such as superiors or coworkers. Those who have better skills in providing self-feedback can maintain self-confidence until their new ideas or behaviors are officially accepted by the organization.
If power distance is high, individuals may find it more difficult to apply this strategy. In high power distance organization emphasizing hierarchy, employees are expected to follow strict guideline and routine set by superior or officially by the organization. Then, individuals have less to use those self-leadership strategies, which result in less innovative behavior. Similarly, in the second stage of the innovation process, individuals need to promote their new ideas to get legitimacy and support inside the organization(Scott \& Bruce, 1994). If power distance is low, the organization can provide psychological climate in which individuals feel more freedom to approach others regardless of status. Then, individuals with high level of self-leadership can persuade others to support their new ideas, which eventually result in innovative work behavior. Thus, we propose the following hypothesis

\section{H3: Self-leadership mediates the relationship} between power distance and innovative work behavior.

Self-leadership is promoted or discouraged by uncertainty avoidance, too. According to Hofstede(1980), high uncertainty avoidance cultures value the leadership styles that promote strict planning, stability, formal rules, and expert skills whereas the organizations with low uncertainty avoidance encourage employees' participative decision making and view employees' leadership abilities, providing more 
favorable environment for self-leaders. Low uncertainty avoidance cultures also value more flexibility, mobility, and general rather than specialized skills, many of which corresponds to self-leadership(Alves et al., 2006; Dickson et al, 2003). Consequently, such social and organizational cultural values are internalized into individuals.

Therefore, individuals with high uncertainty avoidance become to prefer the current work routines that are clearly connected with external rewards than the new ideas that are related with no or abstractive rewards until such ideas are accepted by the organization(Alves et al., 2006). Then, their ideas are less likely to develop into concrete innovative behaviors. Individuals with low uncertainty avoidance can provide selfmotivation by creating internal reward(e.g., enjoying the nature of new ideas) and continue working on refining such ideas. Thus, good skill using self-reward strategy will benefit new but rough ideas to develop into innovative behaviors.

In sum, individuals' different uncertainty avoidance level leads to differences in manifestation of innovative work behavior. For instance, managers in Great Britain, a low uncertainty avoidance culture, expect more improvisation from subordinates whereas managers in Germany, high uncertainty avoidance culture, expect reliability and punctuality(Stewart et al., 1994). Beside this, there is currently little empirical evidence on its relationship with self-leadership because uncertainty avoidance is relatively less studied compared to power distance. Some indirect evidence is helpful for this rationale, though. For example, uncertainty avoidance is closely related to the attribute of controllability that is critical in self-leadership. Compared to low uncertainty avoidance cultures, individuals from high uncertainty avoidance culture were significantly more sensitive to controllability in perceiving strategic issues(Barri \& Glynn, 2004). Also it is reported that the more people feel uncertainty, people cope with uncertainty by self-regulation either reducing self-discrepancies(Roney \& Sorrentino, 1995).

In sum, while culture influences individual employees' innovative work behavior directly, it can be actually though encouraging or discouraging the initiation and demonstration of self-leadership strategy, which in turn boosts or reduces innovative behaviors. We intend to test the role of self-leadership in the relationship between uncertainty avoidance and innovative work behavior by proposing the following hypothesis.

\section{H4: Self-leadership mediates the relationship} between uncertainty avoidance and innovative work behavior.

As proposed in introduction, we explore the proposed research questions through comparing workers in Korea and China. This is due to 
both theoretical and practical reasons. Theoretically, this study can provide knowledge on similarities and differences between Korean and Chinese that previous studies neglected. The majority of previous studies, regardless cross-cultural or cross-national, is limited in that they compared prototypical samples from East and West cultures(e.g., comparing Japanese and American) neglecting similarities and differences among East Asian countries. A reason for lack of comparing Korean and Chinese people is that many scholars have identified these societies as similarly rooted in Confucianism(e.g., Hofstede, 1980). Yet, Korea and China have gone through different political and social changes during industrialization and modernization. Bond's(1996) review of several cross-cultural value surveys(the Schwartz Value Survey) suggested varying degrees of value endorsement within East Asian societies including Korea and China. Thus, this study can fill the gap that previous studies neglected.

The second reason is practical purpose. Putting it simply, we are not interested in how different Koreans are from Americans but interested in how they different are from Chinese if we work with Chinese in actual business world. Currently China is the second largest trading partner to Korea since 2010 with trade volume accounting for $22.1 \%$ of Korea. Due to low labor cost, attractive local market with much potential for growth, and other beneficial business opportunities, a huge number of Chinese workers are currently employed by Korean firms, and vice versa. Thus, Korean and Chinese workers' interactions at various levels are currently inevitable and will be more in future. Thus, we believe that examining how key variables related with innovation are similarly or differently interconnected will provide valuable practical knowledge and insights.

Supporting this, with regards to Hofstede's cultural dimensions, Korean and Chinese culture are different as much as similar(McLean, 2006; Wang et al., 2005). Korea and China more differences in power distance(Korea $=60$, China $=80)$ and uncertainty avoidance(Korea $=85$, China $=30$ ) compared with the difference in individualism-collectivism dimension is relatively small $($ Korea $=18$, China $=20) .{ }^{1}$ ) Thus, knowledge on power distance, uncertainty avoidance, self-leadership, and innovative work behavior and their interconnections would bring strategical benefits to an organization in human resources management, negotiation in business deals, developing a desirable organizational culture within an organization with employees of diverse cultural composition.

1) While they are also different in masculinity/femininity $($ China $=66$, Korea $=39$ where high score corresponds to masculinity), we do not focus on it considering its relevance to innovation is quite low. 


\section{Method}

\section{Participants and Procedure}

Data was collected through a survey conducted in Korea and China. The survey questionnaire was prepared both in Korean and Chinese languages using back translation procedure to minimize the biases resulting from translation. The final questionnaire was distributed to the employees working for 20 Chinese and 20 Korean companies in various industries through authors' personal network. 510 questionnaires were returned with a response rates of 58\% for Chinese and 55\% for Korean. Finally, a total of 482(278 Chinese, 204 Korean) responses were selected excluding incomplete entries and outlier. Overall, both Korean and Chinese respondents can be characterized as a young white collar workers $(M=35.34, S D=$ 14.11 for Korean; $M=28.66, S D=12.62$ for Chinese) with high education level working at urban located firms. Slightly more male respondents were included in Korean group $(54.8 \%)$ whereas female respondents(60.1\%) were dominant in Chinese group. Both groups had high education level: 68.7 percents of Korean and 63.7 percents of Chinese respondents are bachelor's degree or higher degree holders. Job types included various areas including manufacturing, service, financial, IT, and public sector and the largest number of respondents worked in the service sector(25.7\% for Korean,
$27.7 \%$ for Chinese).

\section{Measurements}

\section{Innovative work behavior}

Innovative work behavior was measured by nine question items developed by Janssen(2000). Questions are divided into three categories:(1) idea generation, (2) idea promotion, (3) idea realization. Sample items are "Creating new ideas for difficult issues" for idea generation, "Mobilizing support for innovative ideas" for idea promotion, and "Introducing innovative ideas into the work environment in a systematic way" for idea development.

\section{Power distance}

To measure power distance, we used five items that Dorfman and Howell(1988) revised Hofstede(1980)'s four items by criticizing that original items taps power distance at the national level but did not adequately measure individual differences. Sample items are "Managers should make most decisions without consulting subordinates," "Managers should seldom ask for the opinions of employees," and "Employees should not disagree with management decisions.

\section{Uncertainty avoidance}

Uncertainty avoidance was also measured with five items from Dorfman and Howell(1988). Sample items are "Rules and regularities are important because they inform workers what the 
organization expects of them," "Standard operating procedures are helpful to employees on the job." and "Instructions for operations are important for employees on the job."

\section{Self-leadership}

20-item Revised Self-Leadership Questionnaire (RSLQ; Houhton \& neck, 2002) was used. RSLQ consists of items measuring behaviorfocused strategies, natural reward strategies, and constructive thought pattern strategies. Sample items are "I use written notes to remind myself of what I need to accomplish(behavior focused7 strategy)," "I find my own favorite way to get things done(natural reward strategy)" and "I visualize myself successfully performing a task before I do it(constructive thought pattern strategy)." All questions used in the questionnaire are 5-point Likert scale format with the response ranged from 1 (strongly disagree) to 5 (strongly agree).

\section{Results}

\section{Descriptive Analyses}

We first ran a measurement model test to check if the data from both Korean and Chinese respondents had an equivalent factor structure. To do so, the survey items with low correlations with other items were initially excluded through reliability analysis and a confirmatory factor analysis was run. In order to be comparable across sample, each of Korean, Chinese, and combined samples should show good and equivalent model fits.

Items with low correlations with other items were initially excluded through reliability analysis. Also, we deleted the factors of which weights were less than .50. Then, items of which $\mathrm{CR}$ were more than .70 but AVE(Average Variance Extracted) were less than .50, and the standardized regression weights were over .50 remained. Also, we discussed whether problematic items had good a face validity in both Korean and Chinese languages. For instance, problematic items were written too broad or ambiguously so they would produce different connotative meanings to different respondents. As a result, all items for power distance and uncertainty avoidance remained and three items were dropped from self-leadership. They are "I find my own favorite way to get things done," "I feel guilt when I perform and task," "I keep track of my progress on projects." No item was dropped from innovative work behavior measure.

The CFA result of the sample combined with Korean and Chinese respondents showed good fit indices $\left(\chi^{2} / d f=2.946\right.$, CFI $=.933$, NFI $=$ .903 , TLI $=.918$, RMSEA $=.064)$. Korean respondents showed good model fits $\left(\chi^{2} / d f=\right.$ 1.882, CFI $=.965$, NFI $=.929$, TLI $=.949$ RMSEA $=.066)$ and so did Chinese respondents $\left(\chi^{2} / d f=1.324, \mathrm{CFI}=.986, \mathrm{NFI}=.948, \mathrm{TLI}\right.$ $=.981$, RMSEA $=.056$ ). Finally, all variables based on the remained items showed reliabilities 
that met the requirements of Nunnally(1978) that the Cronbach's a value is higher than .70 . Therefore, it was concluded that the data from both Korean and Chinese respondents have similar factor structures enough for comparison.

Multiple t-tests were run to compared Korean and Chinese respondents' scores in all measures. Korean respondents showed higher uncertainty avoidance than Chinese whereas Chinese respondents showed higher power distance than Korean(See Table 1). Chinese respondents scored higher both in power distance $(M=1.90, S D=$ .59 for Korean, $M=2.44, S D=.71$ for Chinese) and uncertainty avoidance( $M=4.12$, $S D=.66$ for Korean, $M=3.92, S D=.56$ for Chinese). Chinese respondents also evaluated the level of their innovative work behavior and self-leadership higher than Korean respondents (see Table 1). As innovative work behavior is a self-reported measure, comparisons at its absolute values may not be completely free from the biases caused by translation, differences in connotative meaning of the questions, and psychometric differences such as central tendency.
Thus, we focused on the patterns of relationships among variables based on the correlational analyses and the structural model test in the next section.

\section{Hypothesis Testing}

\section{Correlation Analysis}

As predicted, negative correlations were found between power distance and innovative work behavior $(r=-.370, p<.01$ for Korean, $r$ $=-.357$ for Chinese). power distance was also negatively related to self-leadership $(r=-.176$ for Korean, $r=-.184$ for Chinese). Self- leadership showed high correlations with innovative work behavior in both groups(see Table 4 for details). Surprisingly, positive relationship was found between uncertainty avoidance and between innovative work behavior, and uncertainty avoidance and self-leadership. Uncertainty avoidance showed positive correlations with innovative work $\operatorname{behavior}(r=.346, p<.01$ for Korean; $r=.549, p<.01$ for Chinese). Uncertainty avoidance also showed positive

Table 1. Results of T-Tests comparing Korean and Chinese Respondents

\begin{tabular}{cccccc}
\hline & \multicolumn{3}{c}{ Korean } & \multicolumn{3}{c}{ Chinese } \\
\cline { 2 - 6 } Measurements & $M$ & $S D$ & $M$ & $S D$ & $t$ \\
\hline Power distance & 1.90 & .59 & 2.44 & .71 & $8.93^{* * *}$ \\
Uncertainty avoidance & 4.12 & .66 & 3.92 & .56 & $.3 .54^{* * *}$ \\
\cline { 2 - 6 } Self-leadership & 3.53 & .47 & 3.77 & .45 & $5.44^{* * *}$ \\
\cline { 2 - 6 } Innovative work behavior & 3.34 & .66 & 3.55 & .52 & $3.47^{* *}$ \\
\hline
\end{tabular}

Note. ${ }^{*} p<.05 .{ }^{* *} p<.01,{ }^{* * *} p<.001$ 
correlations with self-leadership $(r=.596, p<$ .001 for Korean, $r=.600, p<.001$ for Chinese). To examine if there was any culture specific aspect of self-leadership, additional regression analyses were run with each self-leadership strategy as independent variables. Behavioral strategy was the one that distinguishes Chinese and Korean samples: it was a significant predictor of innovative work behavior for $\operatorname{Korean}(b=.212, p<.001)$ but not for Chinese $(b=.068$, n.s. $)$. Correlational coefficients are present in Table 2. Based on correlational analyses, Hypothesis 1 was supported whereas Hypothesis 2 was not.

\section{Structural Model Test}

The results of correlation analyses should be interpreted with caution. Because the respondents in two countries answered for the questionnaire with a different language, their responses can have different central tendency or connotative meanings, the comparisons of absolute values in each variable are not adequate. Thus, comparing relationship pattern among variables is more desirable to minimize such biases and we ran structural equation modeling tests for the next analysis.

Two models were evaluated to examine potential mediation effects. Initial model postulated full mediation relationships between power distance, uncertainty avoidance, and innovative work behavior with self-leadership as the mediating variable. Alternative model was the partial mediation model which has direct paths between power distance, uncertainty avoidance, and innovative work behavior. We

Table 2. Correlation Coefficients and Reliabilities among Measures ( $N=482 ; 278$ Chinese, 204 Korean)

\begin{tabular}{|c|c|c|c|c|c|c|c|}
\hline & 1 & 2 & 3 & 4 & 5 & 6 & 7 \\
\hline 1. Power distance & $.755(.733)$ & $.225^{*}$ & -.184 & -.047 & .060 & .016 & $-.357^{*}$ \\
\hline 2. Uncertainty avoidance & $.171^{*}$ & $.780(.824)$ & $.600^{* * * *}$ & $.479^{* *}$ & $.390^{* *}$ & $.315^{* *}$ & $.549^{* * *}$ \\
\hline 3. Self-leadership & $-.176^{*}$ & $.596^{* * *}$ & $.898(.870)$ & $.939^{* *}$ & $.877^{* *}$ & $.762^{* *}$ & $.824^{* * *}$ \\
\hline 4. Behavioral & -.108 & $.375^{* *}$ & $.911^{* *}$ & $.802(.813)$ & $.701^{* *}$ & $.632^{* *}$ & $.608^{* *}$ \\
\hline 5. Thought & -.091 & $.390^{* *}$ & $.824^{* *}$ & $.571^{* *}$ & $.765(.737)$ & $.565^{* *}$ & $.572^{* *}$ \\
\hline 6. Reward & $-.122^{*}$ & $.312^{* *}$ & $.741^{* *}$ & $.578^{* *}$ & $.485^{* *}$ & $.811(.756)$ & $.561^{* *}$ \\
\hline 7. Innovative work behavior & $-.370^{* *}$ & $.346^{* * *}$ & $.742^{* * *}$ & $.548^{* *}$ & $.490^{* *}$ & $.561^{* *}$ & $.900(.931)$ \\
\hline \multicolumn{8}{|c|}{$\begin{array}{l}{ }^{*} p<.05,{ }^{* *} p<.01,{ }^{* * *} p<.001 \\
\text { Correlations in upper right of diagonal }=\text { Chinese; Italic number }=\text { Cronbach } a \text { for Korean sample; Italic number in } \\
\text { parenthesis }=\text { Cronbach } a \text { for Chinese sample }\end{array}$} \\
\hline
\end{tabular}


Table 3. Results of Bootstrap Analyses for the Mediation Effects by Self-Leadership

\begin{tabular}{|c|c|c|c|c|c|}
\hline Indirect effect & Participants & $\beta$ & $\begin{array}{c}C R \\
\text { (Lower) }\end{array}$ & $\begin{array}{c}C R \\
(\text { Upper })\end{array}$ & $p$ \\
\hline \multirow[t]{2}{*}{$\begin{array}{c}\text { Power distance } \\
\rightarrow \text { Innovative work behavior }\end{array}$} & Chinese & -.191 & -.409 & -.047 & .002 \\
\hline & Korean & -.119 & -.273 & -.028 & .002 \\
\hline \multirow[t]{2}{*}{$\begin{aligned} & \text { Uncertainty avoidance } \\
-> & \text { Innovative work behavior }\end{aligned}$} & Chinese & .487 & .282 & .752 & .002 \\
\hline & Korean & .472 & .254 & .699 & .002 \\
\hline
\end{tabular}

used a bootstrapping method. A typical analysis method of SEM is problematic due to its low power in detecting intervening variable effects and its lack of quantification of the indirect effect. Thus, it was to test the significance of the indirect effect itself. The path coefficient for the indirect effect represents the change in functional outcome for every unit change in power distance and uncertainty avoidance that is mediated through self-leadership. Bootstrapping the mediated effect tends to have the highest power and the best type I error control. A bootstrap approximation with 2000 iterations yielded a percentile-based confidence interval. If zero is not between the lower and upper bound, it is concluded that the indirect effect is significantly different from zero, which indicates mediation present.

For both Korean and Chinese respondents, indirect effects of power distance and uncertainty avoidance through self-leadership were apparent whereas no direct effects from power distance and uncertainty avoidance to innovative work behavior were found. The indirect effects were tested using a bootstrap estimation approach with 1000 samples(Shrout \& Bolger, 2002). The results indicated the indirect coefficients of self-leadership were significant for power distance and innovative work behavior for both Korean and Chinese $(\beta=-.119, p<.01$ for Korean; $\beta$ $=-.191, p<.01$ for Chinese). Indirect effects between uncertainty avoidance and innovative work behavior were also found significant for both samples $(\beta=.472, p<.01$ for Korean; $\beta$ $=.487, p<.01$ for Chinese). The results of bootstrap analyses are present in Table 3 . Therefore, Hypothesis 3 and 4 were supported based on these results.

Table 4 displays the fit indices of initial and competing models. Initial model of Korean respondents produced satisfactory model fit indices, $X 2 / d f=1.961, \mathrm{CFI}=.958, \mathrm{NFI}=$ .919, TLI $=.942$, RMSEA $=.069$. Full mediation model also resulted in good model fit indices, $X 2 / d f=1.973, \mathrm{CFI}=.955$, NFI $=$ .915 , TLI $=.941$, RMSEA $=.069$. To examine 
Table 4. Results of Structural Model Tests for Hypothesis Model and Competing Model

\begin{tabular}{|c|c|c|c|c|c|c|c|c|}
\hline & & $x^{2}$ & $d f$ & $x^{2 / d f}$ & CFI & $N F I$ & $T L I$ & RMSEA \\
\hline \multirow{3}{*}{ Korean } & $\begin{array}{l}\text { Hypothesis model } \\
\text { (partial mediation model) }\end{array}$ & 94.120 & 48 & 1.961 & .958 & .919 & .942 & .069 \\
\hline & $\begin{array}{l}\text { Competing model } \\
\text { (full mediation model) }\end{array}$ & 98.642 & 50 & 1.973 & .955 & .915 & .941 & .069 \\
\hline & $\begin{array}{c}\text { Difference between initial model } \\
\text { and competing model }\end{array}$ & 5.522 & 2 & & & & & \\
\hline \multirow{3}{*}{ Chinese } & $\begin{array}{l}\text { Hypothesis model } \\
\text { (partial mediation model) }\end{array}$ & 88.910 & 48 & 1.852 & .964 & .925 & .950 & .055 \\
\hline & $\begin{array}{l}\text { Competing model } \\
\text { (full mediation model) }\end{array}$ & 91.587 & 50 & 1.832 & .963 & .923 & .951 & .055 \\
\hline & $\begin{array}{l}\text { Difference between initial model and } \\
\text { competing model }\end{array}$ & 2.677 & 2 & & & & & \\
\hline
\end{tabular}

if the partial mediation model was better than the full model, Chi-square difference test was run but no significant improvement was found. Overall model fit indices did not change or not improve either. In structural model analysis, a parsimonious model is better if overall fit indices are similar. Thus, the full mediation model was chosen as the best model for Korean group. The initial model of Chinese respondents also showed good fit indices $(\chi 2 / d f=1.852$, CFI $=.964$,
$\mathrm{NFI}=.925$, TLI $=.950$, RMSEA $=.055)$. Full mediation model also produced good model fit indices, $\chi 2 / d f=1.832, \mathrm{CFI}=.963$, NFI $=$ .923, TLI $=.951$, RMSEA $=.055$. Model fits in full mediation model did not improve significantly.

Therefore, the full mediation model was chosen as the best fit model for both Korean and Chinese groups. Final structural models present in Figure 1 show that power distance

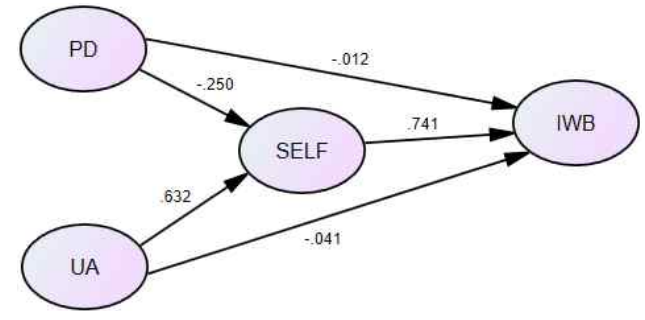

Korean

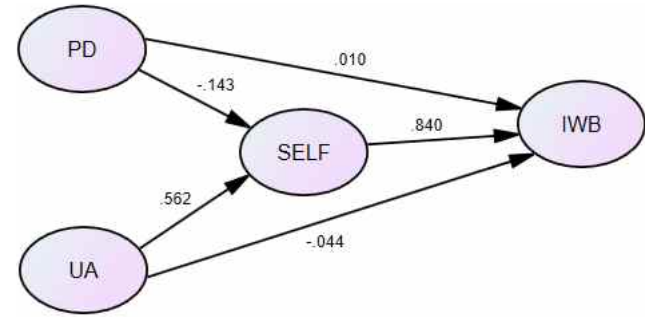

Chinese

Figure 1. Structural Model 
and uncertainty avoidance are different in their relationships with self-leadership across two groups of respondents. power distance is related to self-leadership for both Korean respondents $(\beta$ $=-.250, p<.01)$ and Chinese $(\beta=-.143, p$ $<$.001). In contrast, similar with the findings from correlation analyses, paths from uncertainty avoidance to self-leadership are positive for both Korean and Chinese respondents $(\beta=.632, p<$ .01 for Korean, $\beta=.562, p<.01$ for Chinese). Self-leadership is a strong predictor of innovative work behavior for both Chinese and Korean respondents. Path coefficients are quite high for both $\operatorname{Korean}(\beta=.741, p<.001)$ and Chinese $(\beta=.840, p<.001)$.

\section{Discussion}

The goal of the present study was to investigate if individual employees' cultural value orientations, which was measured by power distance and uncertainty avoidance, are related to their innovative work behavior. We specially focused on the mediating effects of self-leadership in the relationships between power distance and uncertainty avoidance, and innovative work behavior in order to identify working mechanism at individual level. In addition to those goals, we also aimed to test the validity of the proposed hypotheses regardless cultures by comparing the data obtained from Korean and Chinese employees.

\section{Findings and Implications}

The results of descriptive data analyses demonstrated that Chinese respondents still showed higher power distance than Korean respondents whereas Korean respondents showed higher uncertainty avoidance than Chinese respondents, of which results are similar with those reported in Hofstede's most recent study (2001). However, the gap in uncertainty avoidance between two countries became smaller in uncertainty avoidance(4.12 for Korean, 3.92 for Chinese) in our sample. One possible interpretation is that although China experienced tremendously fast transition throughout various areas in the society since the 'Opening of China,'(Yang, 2014), the Chinese people became accustomed to the pace of change because the society has been stable recently, and as a result, Chinese people became to feel less uncertainty. An accurate reason for why uncertainty avoidance levels became smaller across two countries cannot be answered in this study due to small sample size and limited numbers of variables. However, this study confirms that the levels in individuals' culture value orientations are constantly changing and that it is necessary to continue monitoring the pattern of change for practical purposes.

As predicted, individuals' cultural value orientations were significantly related with their innovative work behavior supporting our rationale that cultural values enhance or discourage 
individuals' efforts in innovation. Yet, uncertainty avoidance and power distance were related with innovative work behavior in somewhat different ways. power distance was negatively related with innovative work behavior for both Korean and Chinese respondents. This result supports the findings in previous studies(Bialas, 2009; Herbig \& Dunphy, 1998; Van Evergingen \& Waarts, 2003). Surprisingly, uncertainty avoidance was positively related to innovative work behavior both for Chinese and Korean respondents. This is an opposite result from the prediction based on the previous literature(Jansen, Van Den Bosch \& Volberda, 2006; Miron, Erez, \& Naveh, 2004; O’Reilly, et al., 1991; Shane, 1993; Williams \& McQuire, 2005). We interpret that this result might be related with dual meanings of innovative work behavior. The respondents might have thought of different type of innovative behaviors, perhaps more related with incremental innovation than with radical innovation. Incremental innovation builds upon the established knowledge rather than completely new ideas to steadily improves the methods or materials used in the organization(Hill \& Rothaermel, 2003). Compared with radical innovation, incremental innovation aims for secured success because it primarily focuses developing familiar routine in work into a better one(Markus, 2012; Wang, 2012). If this is the case, individuals with high uncertainty avoidance may avoid radical new ideas but may pursue incremental changes because they prefer secure achievements. We conducted further analyses to examine this possibility. We ran a regression analysis with only items relevant to incremental innovation from the total items in innovative work behavior measure. As expected, beta weight by uncertainty avoidance increased from .341 to $.371, p<.001$. This result supports our interpretation that uncertainty avoidance is rather a positive predictor of innovative work behavior for incremental innovation related outcomes.

Furthermore, if the global economy is in an unstable state, high uncertainty avoidance might mean that the employees face not only more challenges but also more opportunities. Ironically, this may push firms to make more efforts to seek for innovation as a way to escape from unstable firm situation, which may bring more innovative work behaviors. For example, many Japanese and German firms make efforts to reduce uncertainty through greater investments in employee training and in information technology, which helps them gain differentiated advantage in the international market(Gupta, 2011). In fact, there is empirical evidence supporting this rationale. As discussed in introduction, uncertainty sometimes does not affect innovation(Grinstein, 2008) or even has a positive relationship with it(Gupta, 2011). For example, Ladbury \& Hinz(2009) point out people in high uncertainty avoidance make choices for uncertain outcomes if they involve gains. Yang(2014) found that income is related with uncertainty avoidance and outcome: as 
income increases, people in even high uncertainty avoidance culture are more willing to take risks. Together with those findings, our study suggests that uncertainty avoidance should not be just considered as a simple barrier to innovative work behavior but that more complex situational factors exist to explain such relationship.

Hypotheses on the mediation effects of selfleadership were also supported. As predicted, self -leadership mediated the relationship between uncertainty avoidance and innovative work behavior for both Korean and Chinese respondents. Based on this finding, we claim the role of leadership as a direct absorber of an organization's culture. Those with a high level of self-leadership tend to take initiatives and drive the oneself to achieve goals with minimum need of external guidance. Thus, they can be more sensitive to the culture within organization that may influence employees' work outcome. It is well formulated that culture's influences on individual's behavior are through self-concept (Markus \& Kitayama, 1991). Our study shows that as for innovative work behavior it is particularly through leadership based self-concept.

We view that our study has contributions in following points. The first is an affirmation of the importance of self-leadership between culture's influence and manifestation of innovative work behavior. innovative work behavior is a self-driven work behavior compared to other types of work behaviors. Thus, it should be dependent of internal motivation and direction. Self-leadership is not what a leader influences others but what an individual influences oneself. Because it requires clear self-direction and strong motivation, its positive link to innovative work behavior is expected but previous research has neglected examining the mediation effect of self-leadership on innovative work behavior. Our study provides some meaningful answers to this research gap.

Second, this study also has contribution to the research linking culture and self-leadership. Self-leadership is studied by many angles but its link to culture is a few while a few of studies tried to validate the concepts of self-leadership across different cultures(Neubet \& Wu, 2006). Especially, researchers claimed the needs for empirical research to investigate the practice of self-leadership in other cultures(Alves at el., 2006). Our research is one of the efforts to fill the lacuna.

To look at this issue more carefully, this study shows the pros and cons of a crossnational study. The most important benefit is that we now have a more confidence in a theory by finding a universal pattern of relations among variables across different samples. On the other hand, a significant challenge is that if we do not find consistent results across different samples, the results mean either that our theory is not valid or that there exist possible unique social and national factors that influence innovative work behavior. Our results show both of them exist to some different extent in this 
study. A universal finding is that individuals' cultural value orientation is an important key variable to understand their innovative work behavior. Both Korean and Chinese respondents' innovative work behavior were related with uncertainty avoidance and power distance with a bit variation, indicating that initiation, progress, and final demonstration of innovative work behavior seems dependent of cultural values. In this sense, there is need to emphasize that innovation is a collective work based on interactions among different individuals. No matter how an individual is potentially innovative, his/her final behavioral outcome is unlikely to lead to innovation unless the organization builds environment that encourage innovative work behavior. Innovative individuals would not make efforts to produce innovative work behavior because such behaviors can be seen as unfitting actions in organization. Our findings suggest that building environment context nurturing the individuals' freedom from hierarchy pressure is as equally important as selecting, training, and motivating capable innovative individuals.

Some notable differences across two samples were found, too. Especially, the relationship strength between power distance and innovative work behavior differed across Korean and Chinese respondents. This result suggests that managers working at multinational environment (i.e., Korean-Chinese joint firm) needs to monitor and selectively encourage or discourage certain behaviors related to power distance. For example, managerial actions emphasizing hierarchical culture(i.e., excessive top-down decision making or order making) should be monitored with more caution for Chinese workers.

In the global world, managers and workers cannot avoid a difficult task, increasing cultural diversity in the organization. Creativity research constantly reveals that diversity is a great asset to bring creativity and innovation(Li et al., 2015; Shin, Kim, \& Han, 2009). While this is a good sign, to many managers, how to deal with workers from different cultural backgrounds, is a very challenging task. A famous cultural anthropologist and psychologist, Richard Schweder(1991), mentioned that in order to achieve benefits and harmony from this multi-cultural world, we should seek for universal truth but not in a dogmatic way. Our finding echoes the same wisdom is valid in organizational management, too.

\section{Limitations and Suggestions}

This study also has several limitations. First, this study does not rule out the interplay of the organizational culture and societal culture in terms of influences on individuals. In many cases, societal culture is reflected in organizational culture(i.e., Japanese firms showing strong collectivism) whereas in other cases, the culture of an organization is purposely fabricated to be different from the dominant social culture for 
certain purposes(i.e., Samsung Electronic's for practical insights.

organizational culture promoting individual initiates and free hierarchy). In such cases, social culture pre-internalized within individuals and

\section{References} organizational culture may interact to affect them in a complex forms. Whether creating new culture is possible or not is still on debate(Hong \& Mallorie, 2004). Thus, it is valuable for the management of organization to discern to what extent an individual's cultural value and innovative behaviors are affected by different sources of cultures. Collecting data from a same industry in different countries can be an alternative way to control such biases.

Another limitation is that this study could not examine proposed research questions by different types of organizations. Lee(2003) demonstrated that individuals' cultural orientation has different effects on the employees to resist against the team organization more in manufacturing firms than in other firms because high power distance makes individuals to resist team organization which ensure more freedom in communications and more empowerment, which is opposite from the hierarchy observed in high power culture. Similarly, Hofstede(1980) once claimed that the a organizational structure providing a high level of freedom as well as responsibility does not work well in countries with high power distance. Therefore, while we focus on individual level cultural orientation in this study, future studies are encouraged to examine such various effects by organization type

이준호 (2003). 우리나라 조직구성원들에 인지 된 문화적 가치관이 팀제에 대한 저항과 조직성과에 미친 영향. 조직과 인사관리연 구, 27(4), 25-57.

신용국, 김명소, 한영석. (2009). 셀프리더십 척 도(Revised Self-Leadership Questionnaire) 타당 화 연구: 우리나라 대학생을 중심으로. 한 국심리학회지: 학교, 6(3), 313-340.

양현철, 정현선, 박동건 (2013). 직장 유연성이 신입사원급 직장인들의 이직의도와 혁신 적 업무행동에 미치는 영향: 일-성장 균 형, 조직지원인식의 매개 효과 및 셀프 리더십의 조절 효과를 중심으로. 한국심리 학회지: 산업 및 조직, 26(1), 149-176.

Alves, J. C., Lovelace, K. J., Manz, C. C., Matsupura, D., Toyasaki, F. \& Ke, K. (2006). A cross-cultural perspective of self-leadership. Journal of Managerial Psychology, 21(4), 338359.

Amabile, T. M., Conti, R., Coon, H., Lazenby, J., \& Herron, M. (1996). Assessing the work environment for creativity. Academy of Management Journal, 39(5), 1154-1184.

Anderson, J. S., \& Prussia, G. E. (1997). The self-leadership questionnaire: Preliminary assessment of construct validity. The Journal of Leadership Studies, 4, 119-143.

Barri, P. S., \& Glynn, M. A. (2004). Cultural variations in strategic issue interpretation: 
Relating cultural uncertainty avoidance to controllability in discriminating threat and opportunity. Strategic Management Journal, 25, 59-67.

Bialas, S., (2009). Power distance as a determinant of relations between managers and employees in the enterprises with foreign capital. Journal of Intercultural Management, 1(2), 105-115.

Carmeli, A., Meitar, R., \& Weisberg, J. (2006). Self-leadership skills and innovative behavior at work .International Journal of Manpower, 27(1), 75-90.

Daniels, M. A., \& Greguras, G. J. (2014). Exploring the nature of power distance: Implications for micro and macro-level theories, processes, and outcomes. Journal of Management, 40(5), 1202-1229.

Dickson, M. W., Den Hartog, D. N., \& Mitchelson, J. K. (2003). Research on leadership in a cross-cultural context: making progress, and raising new questions. Leadership Quarterly, 14, 729-768.

Diliello, T. C., \& Houghton, J. D. (2006). Maximizing organizational leadership capacity for the future: Toward a model of self-leadership, innovation and creativity. Journal of Managerial Psychology, 21, 319-337. Dorfman, P. W., \& Howell, J. P. (1988). Dimensions of national culture and effective leadership patterns: Hofstede revisited. Advances in International Comparative Management, 3, 127-149.

Erez, M., \& Nouri, R. (2010). Creativity: The influence of cultural, social, and work contexts. Management and Organization Review,
6(3), 351-370.

Gelfand, M. J., Erez, M., \& Aycan, Z. (2007). Cross-cultural organizational behavior. Annual Review of Psychology, 58, 479-514.

Grinstein, A. (2008). The effect of market orientation and its components on innovation consequences: a meta-analysis. Journal of the Academy of Marketing Science, 36(2), 166-173.

Goldsmith, R., \& Witt, T. (2005). The predictive validity of an opinion leadership scale. Journal of Marketing Theory and Practice, 28-35.

Gupta, V. (2011). Cultural basis of high performance organizations. International Journal of Commerce and Management, 21(3), 221-240.

Hannay, M. (1991). The cross-cultural leader: the application of servant leadership theory in the international context. Journal of International Business and Cultural Studies, 1, 1-12.

Herbig, P., \& Dunphy, S. (1998). Culture and innovation. Cross-Cultural Management: An International Journal, 5(4), 13-21.

Hill, C. W. L., \& Rothaermel, F. T. (2003), The performance of incumbent firms in the face of radical technological innovation. Academy of Management Review, 28(2), 257-274.

Hofstede, G. (1980). Culture's consequences: International differences in work-related values. Sage, Beverly Hills: CA.

Hofstede, G. (2001). Culture's Consequences: Comparing Values, Behaviors, Institutions and Organizations across Nations, 2nd ed. Sage, Thousand Oaks: CA.

Hong Y-Y., \& Mallorie, L. A. (2004). A dynamic constructivist approach to culture: Lessons learned from personality psychology. Journal of 
Research in Personality, 38, 59-67

Howell, J. (2005). The right stuff: Identifying and developing effective champions of innovation. The Academy of Management Executive, 19(2), 108-119.

Howell, J., \& Higgins, C. (1990). Champions of change: identifying, understanding, and supporting champions of technological change. Organizational Dynamics, 19(1), 40-55.

Houghton, J. D., \& Neck, C. P. (2002). The revised self-leadership questionnaire: Testing a hierarchical factor structure for self-leadership. Journal of Managerial Psychology, 17, 672-691

House, R. J., Hanges, P. J., Javidan, M., Dorfman, P. W., \& Gupta, V. (2004). Culture, leadership, and organizations: The GLOBE study of 62 societies, Sage Publications: Thousand Oaks: CA

Janssen, O. (2000). Job demand, perceptions of effort-reward fairness, and innovative work behavior. Journal of Occupational and Organizational Psychology, 73, 287-302.

Janssen, O. (2004). How fairness perceptions make innovative behavior more or less stressful. Journal of Organizational behavior, 36, 201-215. Jansen, J. P., Van Den Bosch, F. A. J., \& Volberda, H. W. (2006). Exploratory innovation, exploitative innovation, and performance: Effects of organizational antecedents and environmental moderators. Management Science, 52(11), 1661-1674.

Javidan, M. \& House, R. J. (2001). Cultural acumen for the global manager: Lessons from project GLOBE. Organizational Dynamics, 29 (4), 289-305.
Klein K. J., \& Knight, A. P. (2005). Innovation implementation. Current Direction in Psychological Science, 14(5), 243-246.

Kotter, J., \& Schlesinger, L. (1979). Choosing strategies for change, Harvard Business Review, 57(2), 106-114.

Lyons, B., \& Henderson, K. (2005). Opinion leadership in a computer-mediated environment. Journal of Consumer Behavior, 4(5), 319-329.

McLean, L. D. (2005). Organizational culture's influence on creativity and innovation: A review of the literature and implications for human resource development. Advances in Developing Human Resources, 7(2), 226-246.

Manz, C. C. (1992). Self-leading work teams: Moving beyond self-management myths. Human Relations, 45, 1119-1140.

Manz, C. C. \& Neck, C.P. (1999). Mastering self-Leadership: empowering yourself for personal excellence. Prentice-Hall: Upper Saddle River, NJ.

Markus, H. R., \& Kitayama, S. (1991). Culture and the self: Implications for cognition, emotion, and motivation. Psychological Review, 98(2), 224-253.

Miron, E., Erez, M., \& Naveh, E. (2004). Do personal characteristics and cultural values that promote innovation, quality, and efficiency compete or complement each other? Journal of Organizational Behavior, 25, 175-199.

Neck, C. P., Nouri, H., \& Godwin, J. L. (2003). How self-leadership affects the goal-setting process. Human Resource Management Review, 13, 691-707.

Neck, C. P., \& Houghton, J. (2006). Two decades 
of self-leadership theory and research: Past developments, present trends, and future possibilities. Journal of Managerial Psychology, 21, 270-295.

Neubert, M. J., \& Wu, J. C. (2006).An investigation of the generalizability of the Houghton and Neck Revised Self-Leadership Questionnaire to a Chinese context. Journal of Managerial Psychology, 21, 360-373.

Pearce, C. L., \& Manz, C. C. (2005). The new silver bullets of leadership: The importance of self and shared leadership in knowledge work. Organizational Dynamics, 34, 130-140.

Prussia, G. E., Anderson, J. S., \& Manz, C. C. (1998). Self-leadership and performance outcomes: The mediating influence of self-efficacy. Journal of Organizational Behavior, 19, 523-538.

Roney, C. J., \& Sorrentino, R. M. (1995). Reducing self-discrepancies or maintaining self-congruence? Uncertainty orientation, selfregulation, and performance. Journal of Personality and Social Psychology, 68(3), 485497.

Rhyne, L. C., Teagarden, M. B., \& Van den Panhuyzen, W. (2002). Technology-based competitive strategies: the relationship of cultural dimensions to new product innovation. Journal of High Technology Management Research, 13, 249-277.

Schwartz, S. H. (1999). Cultural value differences: Some implications for work. Applied Psychology: An International Review, 48, 23-48.

Shweder, R. A. (1991). Thinking through cultures: Expeditions in cultural psychology. Cambridge,
MA: Harvard University Press.

Scott, S. G., \& Bruce, R.A. (1994). Determinants of innovative behavior: A path model of individual innovation in the workplace. Academy of Management Journal, 37(3), 580-607.

Shalley, C. E., \& Gilson, L. (2004). What leaders need to know: A review of social and contextual factors that can foster or hinder creativity. The Leadership Quarterly, 15, 33-53.

Shane, S. A. (1992). Why do some societies invent more than others? Journal of Business Venturing, 7, 29-46.

Shane, S. A. (1993). Cultural Influences on national rates of innovation. Journal of Business Venturing, 8, 59-73.

Stewart, R., Barsoux, J. L., Kieser, A., Ganter, H. D., \& Walgenbach, P. (1994). Managing in Britain and Germany. London: St. Martin's Press/MacMillan Press.

Shrout, P. E., \& Bolger, N. (2002). Mediation in experimental and nonexperimental studies: New procedures and recommendations. Psychological Methods, 7(4), 422-445.

Teece, D., \& Leih, S. (2016). Uncertainty, innovation, and dynamic capabilities. California Management Review, 58(4), 5-12.

Van de Vijver, F. J. R., \& Tanzer, N. K. (2004). Bias and equivalence in cross-cultural assessment: An overview. European Review of Applied Psychology, 54, 119-135.

Venkataraman, S., Shane, S., McGrath, R., \& MacMillan, I. (1993). Some central tensions in the management of corporate venturing, In Birley, S. \& MacMillan, I. (Ed.) 
Entrepreneurship research: Global perspectives (pp. 177-199). Amsterdam.: Elsevier Science Publishers.

Williams, L. K., \& McGuire, S. J. (2005) Effects of national culture on economic creativity and innovation implementation. The Institutions of Market Exchange. Conference Proceedings. Barcelona. International Society for the New Institutional Economics.

Yang, Y. (2014). The Chinese growth miracle. In P. Aghion \& S. Durlauf, Handbook of Economic Growth (pp. 943-1031). Amsterdam: Elsevier.
Yuan, F., \& Woodman, R.W. (2010). Innovative behavior in the work place: the role of performance and image outcomes expectations. Academy of Management Journal, 53(2), 323-342.

1차 원고접수 : 2018. 03. 23 2차 원고접수 : 2018. 07. 12 최종게재결정 : 2018. 08. 08 


\title{
혁신직무행동에 대한 권력거리와 불확실성 회피의 영향: 셀프리더십의 매개효과 ${ }^{*}$
}

김 정 식

판 조 우

광운대학교

\begin{abstract}
본 연구는 종업원들의 불확실회피와 권력거리에 대해 가지는 가치가 혁신직무행동에 미치는 영향을 검증하고 한국과 중국의 기업조직에서 일하는 직원들의 자료를 비교하여 이 관계에 서 자아리더십이 가지는 매개효과를 검증하였다. 총 482 명(한국인 204 명, 중국인 278명)을 대 상으로 수행한 설문자료를 분석한 결과 양 쪽 집단 모두에서 권력거리는 혁신직무행동에 부 적인 관계를 가지며, 불확실성 회피는 혁신직무행동과 정적인 관계를 가진 것으로 나타났다. 특히 셀프리더십은 이들의 관계에서 매개역할을 하는 것으로 나타났다. 본 연구의 결과는 이론적인 측면에서는 개인이 가지는 문화적 가치와 혁신직무행동 간의 유의한 관련이 있으 며 문화가 자아에 영향을 줌으로써 혁신행동이 좌우될 수 있다는 점을 제시한다.
\end{abstract}

주제어 : 문화, 권력거리, 불확실성 회피, 셀프리더십, 혁신직문행동 